[Vicino Oriente XXI (2017), pp. 211-223]

\title{
THE ROLE OF MADĪNA IN THE EMERGENCE OF THE MOSQUE-DĀR AL-IMĀRA COMBINATION: A PRELIMINARY NOTE*
}

\author{
Aila Santi - Sapienza University of Rome
}

This contribution aims to complete the debates concerning the Mosque of the Prophet in Madina with a study focused on the dwelling quarters that populated the surroundings of the blessed building over time (622-711). An in-depth analysis of the sources has allowed us to sketch a reliable plan of the ensemble, finally succeeding in demonstrating that the direct link between the mosque and the caliphal residence - conceivably involving a specific ceremonial purpose - must be post-dated to the Marwānid period.

Keywords: Madīna; Mosque of the Prophet; Umayyads; dār al-imāra

In 1999, Jeremy Johns published a fundamental article ${ }^{1}$ in which he peremptorily shattered one of the essential mainstays in the history of the study of Islamic archaeology: the belief that the house of the Prophet in Madina ${ }^{2}$ - modelled on the architectural prototype of the Arabic $d \bar{a} r^{3}$ - provided the sound basis for the concept of the mosque. The arguments Johns proposed, partially inspired by the remarkable work of Ghazi I. Bisheh, ${ }^{4}$ aimed to point out the conceptual, functional and architectural independence of the "concept of the mosque" from the very first days after the hijra, rejecting the hypothesis that the mosque type evolved from residential architecture much in the same way that basilical churches did. ${ }^{5}$ This groundbreaking view - actually in accordance with the traditional Muslim address - nevertheless left a set of unanswered questions. In particular, as all studies were mostly focused on the mosque, ${ }^{6}$ very little attention was paid to the dwelling quarters of Muhammad and his family in Madīna, and almost no effort at all was made to reconstruct their configuration and their relationship with the adjacent congregational building, nor to ascertain the influence of the complex ${ }^{7}$ on the subsequent urban and architectural

* $\quad$ This article follows a study developed in detail in a paper entitled "Masjidu-hu wa masākinu-hu, 'His Mosque and His dwellings', New Perspectives on the Study of 'the House of the Prophet' in Medina”, which the author has submitted for publication in the volume Liminal Spaces from Sacred to Urban: The Friday Mosque and the City, edited by A. Hilal Uğurlu - Suzan Yalman.

1 Johns 1999.

2 The so-called "domestic theory", developed by Caetani and Creswell, claimed a purely domestic and utilitarian function for the building raised by the Prophet in Madina, which, accordingly, was later referred to in historical and hagiographic sources as a mosque (Caetani 1905, 371-382, 432-449; Creswell 1979, 5-7).

3 «Which in Arabia at that time consisted of a series of small rooms grouped together in an irregular and haphazard fashion around an open courtyard, more or less spacious according to the number and means of the family living in it. If the family was small the rooms were all grouped together on one side, for an Arab's private life required a private courtyard, closed all round, for the various domestic occupations of the womenfolk - weaving, cooking, washing, \&c. - and for the accommodation of the domestic animals, such as dogs, donkeys, poultry, \&c.; the rest of the area was enclosed by a wall» (Creswell 1979, 6-7).

4 Bisheh 1979, 121-128.

5 Cf. Ayyad 2013, 274.

$6 \quad$ Akkouch 1940; Sauvaget 1947; Bisheh 1979; Johns 1999; Abdelrahman 2010; Ayyad 2013.

7 I.e. the ensemble of the congregational mosque and dwelling quarters. 
development of Islām. In this regard, it is important to note that Johns himself, while sharply addressing the "crude caricature" of Creswell's primitive Islām, ${ }^{8}$ put forward the hypothesis that the prototype of the mosque-dār al-imāra combination, ${ }^{9}$ attested later in Bașra, Kūfa, Wāsit and Baghdād, arose for the very first time in Madīna. To back up this suggestion, Johns affirmed that some of the apartments of the Prophet's wives were attached to the mosque and claimed that perhaps the apartment of ' $\bar{A}$ ' isha had stood against the qibla wall. ${ }^{10}$ In an attempt to ascertain this intriguing hypothesis a thorough analysis of the sources has been carried out, which reveals interesting insights into the arrangement of the dwelling quarters adjacent to the mosque and their development over time.

\section{THE MOSQUe AND THE DWELLING QUARTER FROM THE LIFETIME OF THE PROPHET TO 'UMAR'S REBUILDING, 622-638}

Although the plan of the Mosque of the Prophet published by Creswell ${ }^{11}$ - along with his domestic theory - is still the most known, reproduced and quoted in literature, ${ }^{12}$ its weak philological relevance has been widely demonstrated. ${ }^{13}$ Though the site of the Madīnan haram has never been archaeologically investigated, it is possible to identify the boundaries of the earliest phases of the mosque as well as the placement of some of the dwellings raised on the spot thanks to the fundamental work of Samhūdī (d. 1506). ${ }^{14}$ The compendiums of detailed information collected by the scholar - and selected through a trailblazing critical methodology - can be verified thanks to a set of architectural elements which maintained their exact position in the mosque over time, ${ }^{15}$ allowing us to detect the location of the apartments and their architectural relationship with the adjacent mosque with a sufficient degree of precision. ${ }^{16}$

Let us start with ' $\bar{A}$ ' isha's hujra, ${ }^{17}$ namely the modest labin house in which the Prophet lived, died and was buried. Its original position is known since even today it hosts the venerated tomb of Muhammad. As can be observed in the modern plan of the mosque, the small building (6-7 cubits square) ${ }^{18}$ stands in the proximity of the south-eastern corner of

8 Johns 1999, 86-87.

9 Namely, the architectural device featuring a dār al-imāra constructed contiguous to the qibli side of the mosque and with a door providing direct access to the prayer hall, the so-called bāb al-imām.

10 Johns 1999, 86-87.

11 Creswell 1979, 8, fig. 7.

12 Johns 1999, 74-75.

13 Akkouch 1940; Bisheh 1979; Johns 1999; Ayyad 2013.

14 A scholar born in Cairo in 1440 who lived in Madīna for most of his life and conducted the very first accurate reconstruction of the earlier phases of the mosque of the Prophet by collecting a wide number of ancient traditions - such as Ibn Zabāla (d. 814-5), Ibn al-Najjār (d. 1245), al-Mațarī (d. 1340) and al-Marāghī (d. 1413) - complete with his own observations and critical remarks corroborated through a series of evaluations and measurements that the scholar himself carried out in the mosque (Abdelrahman 2010, 104-105; Lecke 1995, xii-xiv)

15 Abdelrahman 2010, 105; Sauvaget 1947, 117-118, 120.

16 Complex reconstruction work has been illustrated by the author in a previous work on the mosque of Madinna (cf. initial note *)

17 Namely the “chamber” (Lane 1968, II, 518)

18 Samhū ${ }^{1} \bar{I}$ I, 143 
the mosque, which encompassed it in 707-710. ${ }^{19}$ According to Samhūdī, ${ }^{20}$ the apartment originally stood at a distance of 20 cubits (ca. $10 \mathrm{~m}$ ) from the eastern wall of the mosque, ${ }^{21}$ which was built where the "Column of Repentance" ${ }^{22}$ stands today. The rebuilding undertaken in 628 after the battle of Khaybar gave the mosque a square form measuring 80 cubits on each side. ${ }^{23}$ The eastern side of the mosque was shifted 10 cubits to the east, reaching the spot currently occupied by the fifth column from the minbar. ${ }^{24}$ This means that the hujra of ' $\overline{\mathrm{A}}$ ' isha was still separate, at a distance of approximately 5 metres from the mosque, and maintained its architectural independence - demonstrating its functional selfsufficiency - until the Marwānid period. ${ }^{25}$ This information is confirmed by Ibn Sa 'd, ${ }^{26}$ who speaks of a path dividing the apartment of ' $\overline{\mathrm{A}}$ ' isha and the congregational building. Moreover, Samhūdī informs us that the $b \bar{a} b$ al-nabì, i.e. the first door on the east side leaving behind the qibla, was opened a long time after the death of Muhammad ${ }^{27}$ and that furthermore the Prophet never used a preferential access to enter the mosque. ${ }^{28}$ This fact is extremely significant for our discussion, because it provides evidence against Johns' argument about the role the Madīnan haram played in influencing the formation of the mosque-dār al-imāra combination. Not only was there no bāa al-nabī during Muhammad's lifetime, but it seems that none of the dwellings of the Prophet's relatives were attached to the enclosure wall of the mosque, nor did they have a private entrance to access it. For instance, we can infer from an episode reported by several sources that Umm Salama's hujra ${ }^{29}$ which was close to that of 'A' isha, stood separately from the mosque's enclosure for she is reported to have built a wall of unbaked bricks in front of it in order to screen herself from public gaze. ${ }^{30}$ As regards the contemporary house of Sawda, which was built

19 When al-Walīd I reconstructed the mosque (cf. below).

20 Samhūdī I, 316.

21 This information refers to the very first phase of the mosque (622-628), predating the battle of Khaybar. At this time the building measured 63 cubits (ca. $30 \mathrm{~m}$ ) from east to west and 70 cubits (ca. $35 \mathrm{~m}$ ) from north to south (Samhūdī I, 238-9, 241). The dwelling quarter was exclusively composed of the chambers of ' $\overline{\mathrm{A}}$ ' isha and Sawda (Ibn Sa 'd I.II, 65.3; Diyārbakrī, 346; Samhūdī I, 325).

22 The fourth column from the minbar (Samhūdī I, 253).

23 The measure of 97 cubits given by Samhūdī (I, 253-4) for the qibla wall seems should be rejected since it does not fit the accounts of early historians (Ibn Zabāla, Yahya al-Husainī and Malīk b. Anas), who unanimously stated that after the rebuilding of 628 the side walls of the mosque reached the spot currently occupied by the fifth ranges of columns to the left and the right of the minbar.

24 Samhūdī I, 253

25 When the mosque was enlarged towards the east for the first time.

26 Ibn Sa'd I, 282.

27 «The Door of the Prophet [Bāb al-Nabī] was so-called because it was located in front of the hut of ' $\overline{\mathrm{A}}$ ' isha [...] and not because he [i.e. Muhammad] used it to enter into the mosque, since it didn't exist in his epoch». Samūdhī I, 496 (transl. by Prof. Mario Casari, who I thank very much for his help in the translation of the sources).

28 The hujra of ' $\bar{A}$ ' isha had just one door, opened in the northern side (Diyārbakrī, 346; Samhūdī I, 325). According to Ibn Sa'd (I, 281) «He [i.e. the Prophet] built three gates, one opposite to qiblah and the second was $B \bar{a} b$ al-Rahmat, which is now called Bāb al-'Atikah; through the third [door, i.e. the bāb Jibrīl], the Apostle of Allāh, may Allāh bless him, used to enter, and this was close to the (quarter of the) children of 'Uthmān»'.

29 Wife of the Prophet since 624 (Roded 2000).

30 Ibn Sa 'd I, 429; Ibn al Najjār, 153; Samhūdī II, 461. 
close to that of ' $\overline{\mathrm{A}}$ ' isha, ${ }^{31}$ we are informed that it was contiguous to the house of the children of 'Uthmān, which stood some metres to the east of the mosque. ${ }^{32}$ Likewise, we have to assume that the house of 'Alī and Fățima was raised at a distance of ca. 10 cubits from the eastern wall of the enclosure, because we are informed that its southern side was attached to the northern side of ' $\bar{A}$ ' isha's hujra, and aligned with it. ${ }^{33}$ The house of Hafșa, daughter of 'Umar b. al-Khaț̣āb and wife of the Prophet, was placed on the qibla side of the haram ${ }^{34}$ Its distance from the mosque can be indirectly inferred, since we are informed that it was incorporated into it during the extension commissioned by 'Uthmān in $649 .{ }^{35}$ 'Uthmān is reported to have enlarged the mosque shifting the qibli wall by 10 cubits (ca. 5 m) southwards with respect to its previous location. ${ }^{36}$ Since the mosque, before this reconstruction, had already been extended in 638 by 'Umar b. al-Khațāa by 10 cubits southwards, ${ }^{37}$ we should argue that the house of Hafșa originally stood at a distance at least equal to this value, since we know that it was not at all affected by this first enlargement. Lastly, Samhūdhī adds that some of the hujrāt of the Prophet's wives were on the north side of the mosque, and that they were only incorporated into the congregational space during al-Walīd's rebuilding phase. Since both 'Umar and 'Uthmān enlarged the mosque northward by, respectively, 30 and 20 cubits, ${ }^{38}$ we can infer that the last dwelling quarter was raised at least ca. $30 \mathrm{~m}$ from the north side of the building. Safiya's house, which, according to traditionalists, ${ }^{39}$ was built at considerable distance from the mosque, was probably part of this compound.

Bringing all these elements together enables us, topographically speaking, to make sense of the arrangement of the complex thanks to a further indication provided by Ibn Kathīr, ${ }^{40}$ namely that the houses of the Prophet's wives were low structures "with near courts", namely with their own courtyards. This information is enlightening if we consider that the apartments are always referred to as ḥujra (pl. huijrāt), literally "chamber”, a word which alone does not indicate a free standing architectural unit ${ }^{41}$ but rather a single element constituting the architectural model of the traditional Arabic dār. ${ }^{42}$ This terminological choice should not be undervalued as it is evidence, confirmed by Ibn Kathīr's substantial information, that all the hujrāt were gathered together in different groups around private and contained courtyards. It was this very intuition which to a great extent influenced Caetani and Creswell in developing the theory of the "House of the Prophet", for they had wrongly understood that the chambers opened onto the courtyard of the mosque, thereby

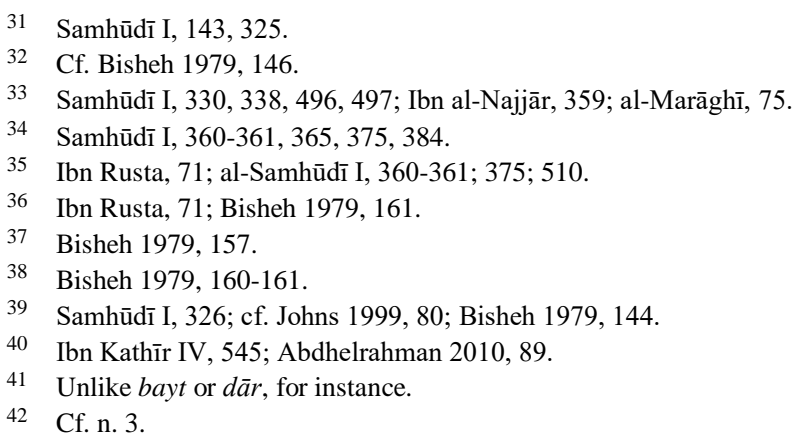


forming, with the latter, a great compound following the $d \bar{a} r$ architectural type. ${ }^{43}$ The foregoing instead allows us to assume that the hujrāt, far from being autonomous and isolated residential units, were part of different $d \bar{u} r$ of more limited dimensions, scattered all around the congregational building (fig. 1). It is important to stress that, according to the sources, at this early stage none of the houses were structurally connected with the mosque, nor did they have a preferential entrance to access it.

\section{THE MOSQUE AND THE DWELLING QUARTERS DURING THE RĀSHIDŪN ERA, FROM 'UMAR'S REBUILDING UP TO 661}

Combining the information provided by the sources, it is possible to go further in the reconstruction of the area adjoining the mosque as it evolved in the Rāshidūn era (fig. 2). A good number of traditions support the assumption that after the death of Muhammad - and perhaps already during the latter years of his life - a proper "aristocratic" district started to develop in the proximity of the congregational building. For instance, Abū Bakr, once appointed caliph, left his residence in the peripheral district of al-Sunh ${ }^{44}$ to reside on the north-east side of the mosque, building a mansion in front of the door known as $b \bar{a} b a l$ Nis $\bar{a}^{\prime} \cdot{ }^{45}$ Through a set of details, we can also infer that the $d \bar{a} r$ of the family of 'Umar must have occupied the area in front of the qibli wall on the east side. We have already mentioned the episode concerning the hujra of Hafșa bint 'Umar, standing on the qibla side of the mosque. Several sources ${ }^{46}$ state that, after its demolition, Hafșa went to dwell in the house of her brother 'Ubayd Allāh b. 'Umar, which was also behind the qibla wall but to the south of it. ${ }^{47}$ These elements, together with the information that the same area, later known as balāt al-A 'dhān, was the private property of 'Umar, ${ }^{48}$ would suggest that the second of the Rāshidūn caliphs owned a $d \bar{a} r$ where he lived together with his family, and of which the apartments of Hafșa and 'Ubayd Allāh constituted just a portion. As for 'Uthmān's residence, we are certain that it stood to the east of the mosque, in front of the $b \bar{a} b J i b r \bar{l} l^{49}$ - which indeed is also known by the name of $b \bar{a} b$ 'Uthmān ${ }^{50}$ - and which, in all likelihood, the third rightly-guided caliph used to enter the mosque. As for 'Alī, we have reason to believe that, before leaving Madina for Küfa in the last years of his troubled caliphate, he resided with his wife Fâtima and their children to the east of the mosque, ${ }^{51}$ in

43 Johns, in dealing with the building function, lists a series of details in which the 'House of the Prophet' departs from the ethnographic model of the Arabic dār: the exaggerated size of the courtyard being «far greater than any purely domestic dwelling is likely to have been» (Johns 1999, 74), the presence of three main entrances instead of the one customary in the traditional domestic architecture of Hijāz, and the fact that the houses of the Prophet's wives - built against the exterior of the courtyard - aside from being an «architectural nonsense» (Johns 1999, 74), were inadmissibly exposed to public gaze.

Țabarī III [1882-85], 1263; Ibn Sa 'd II, 265, 269, and III, 174-175.

45 Although we are not directly informed about this fact, it can be inferred thanks to a statement by Samhūdī (I 499, 528), according to which the house later built by Rayṭa b. Abdul 'Abbās opposite the bāb al-Nis $\bar{a}$ encompassed part of the dār of Abū Bakr.

46 Ibn Rusta, 67; al-Marāghī, 73; Samhūdī I, 360, 361, 510

47 Cf. Bisheh 1979, 144.

48 Whitcomb 2008, 20; al-'Alī 1961, 80.

49 Samhūdī I, 498; Țabarī, V [1893], 2827; Caetani 1914, 232.

50 al-Ḥarbī, 390; Bisheh 1979, 207.

51 Cf. above, 214. 
an apartment that probably, at least initially, ${ }^{52}$ was part of the same compound as those of ' $\bar{A}$ ' isha and Sawda.

The fact that all the caliphs owned a private $d \bar{a} r$ in which they resided in the vicinity of the mosque is essential information, which has never received the attention it deserves. It testifies that the dār al-imāra ${ }^{53}$ at this time was still a distant concept, since the caliphal residences scattered around the mosque of the Prophet had no official nor institutional relevance, constituting a private property of each caliph and their families with an essentially domestic and residential purpose. On the contrary, in this early stage the mosque was the only building in the city devoted to political and governmental purposes ${ }^{54}$ and the closeness of the caliph's residence was a practical requirement to meet the caliph's need to go there several times a day to fulfil his governmental duties. This situation saw the neighbourhoods of the mosque become a highly coveted place of residence for the notables of the city. Living in the neighbourhoods of the blessed mosque of the Prophet, in fact, seemed not only to bestow extraordinary spiritual benefits ${ }^{55}$ but also to represent a sign of social prestige. ${ }^{56}$ We can detect at least some of the dwelling compounds constituting this noble quarter: for example, Samhūdī ${ }^{57}$ informs us that to the west of the mosque, a few metres north of the $b \bar{a} b$ al-Rahmmān, stood an utum ${ }^{58}$ known as Fāri belonging to the Prophet's bard, Hassān b. Thābit, the ruins of which were excavated in 1953 during the first Saudi expansion of the mosque. ${ }^{59}$ Moreover, while reporting the episode of the expropriation and destruction of Hafșa's hujra, Ibn Rusta ${ }^{60}$ adds the noteworthy information that, together with it, part of the mansion ${ }^{61}$ of al- 'Abbās b. 'Abd al-Muttalib ${ }^{62}$ was also brought into the mosque. ${ }^{63}$ We have reason to believe that al- 'Abbās' house stood

52 We are informed that the door linking the apartment of Fātima and 'Alī with the hujra of ' $\overline{\mathrm{A}}$ ' isha was closed after a quarrel between the two women (Ibn al-Najjār, 359; al-Marāghī, 75).

53 Here this term means an independent secular building acting as the seat of political power and the institutional residence of the governor.

54 Pedersen 1991, 644-677; Wellhausen 1902, 6, 81.

55 al-Tirmidhi, n. 594; Abū Dāwūd I, n. 455; al-Baghawī II, 399.

56 The same phenomenon can be observed in coeval early Islamic urban contexts, such as Kūfa (al-Ya 'qūbī, 141-145) Bașra (Ibn al-Faqīh, 231; Massignon 1963, 69; AlSayyad 1991, 49), Fusțāț (Kubiak 1987, 95-96).

57 Samhūdī I, 210-211.

58 A multi-tiered quadrangular building with open yards, enclosed by walls and equipped with fortified entrances, namely a sort of tower-house. They were symbols of Anșāī tribal autonomy and an important component in the prestige of their tribal leaders (Ayyad 2015, 18-19; Lecker 1995, 10, 12-13).

59 Ayyad 2015, 21, fig. 6 (with related bibliography)

60 Ibn Rusta, 71.

61 Note that the word employed here is $d \bar{a} r$, namely the composite architectural type described above (cf. above, n. 3).

62 The half-brother of Muhammad's father. He gave the uterine sister of his wife, Maymūna, to the Prophet in marriage in 629 (Watt 1960). We can speculate that Maymūna's chamber was located within the al-'Abbās $d \bar{a} r$ some 10 metres away from the qibla side of the mosque, following the model of Hafșa's hujra (cf. above)

63 According to Balādhūrī $(1919,20)$, al- 'Abbās' house was incorporated within the mosque during the enlargement ordered by 'Umar (638) and the uncle of the Prophet would have donated it as a gift to Allah and the Muslims, refusing the caliph's offer to purchase it. Nevertheless, this information must be considered with caution, for it may constitute one of the attempts - spread in $9^{\text {th }}$ and $10^{\text {th }}$-century historical literature - of Abbasid propaganda to rehabilitate the controversial figure of the eponymous ancestor of the dynasty (cf. Watt 1960). 
to the right of the qibla, since we know that the left side was inhabited by the family of 'Umar b. al-Khattāab. ${ }^{64}$ In this regard it is remarkable to observe how the area adjoining the qibla does not appear to have been particularly valued during the Rāshidūn era. ${ }^{65}$ In fact, we should bear in mind that Ibn 'Abd al-Muttālib, although a close relative of the Prophet and a member of the ancient Meccan aristocracy, was at the time a controversial character, unpopular with many șaḩāba and with 'Umar himself due to his late and timeserving conversion and his previous anti-Islamic allegiance. ${ }^{66}$ It would seem, conversely, that for the most part both caliphs and esteemed citizens preferred to reside - perhaps following the Prophet or for other topographical reasons as yet unknown to us - on the east side of the mosque. This is where the hero of the Muslim conquest, Khālid b. al-Walīd, is supposed to have lived. According to Abū Ishāa al-Harbī, his house stood not far from the $b \bar{a} b$ 'Uthmān, ${ }^{67}$ some metres in front of the oriental wall of the mosque. ${ }^{68}$ Tabarī's detailed account of the murder of 'Uthmān ${ }^{69}$ provides not only a vague idea of the structure of the caliph's residence ${ }^{70}$ but it also informs us that the residence of 'Amr b. Hazan al-Anșārī was attached to that of the caliph, and thus to the east side of the congregational building. ${ }^{71}$

The overall idea of the complex outlined above, revealing the scarce importance of the area adjoining the qibla and the apparent prominence of the eastern side, would seem to disprove the role of pre-Umayyad Madinna as a model for the later mosque-dār al-imāra combination. ${ }^{72}$ An interesting discussion in this regard concerns the matter of the doors. We have already pointed out that during the lifetime of Muhammad there were no preferential doors for the Prophet to enter the mosque, since the so-called $b \bar{a} b$ al-nabi was opened in front of ' $\overline{\mathrm{A}}$ ' isha's hujra several years after his death. ${ }^{73}$ Likewise, there is no mention of private entrances used by $\mathrm{Abū} \mathrm{Bakr}^{74}$ or 'Umar, nor by 'Uthmān, who, in all likelihood, would have entered the mosque through the $b \bar{a} b$ Jibri $\bar{l}$, the public eastern gate,

64 Cf. above, 215.

65 Note in fact that, besides the Prophet, three of the four rightly-guided caliphs chose to live on the east side of the mosque. The only caliph who settled on the qibla side, 'Umar, in all likelihood owned that plot before being appointed to lead the umma, as his daughter Hafșa is said to have lived there since 624 when the prophet married her (Bukhārī VII, 62, n. 55).

66 He fought against the Muslims at Badr and he joined Muhammad in 630 as he marched on Mecca (Wat 1960).

67 al-Harbī, 391

68 We can infer that it stood some distance from the mosque since it was not affected by the enlargement ordered by al-Walīd I, who extended the east side some 15 metres eastwards (cf. below).

69 Tabarī VI [1898], 3000-3004.

70 Conceivably a $d \bar{a} r$, since we can infer, judging by the successful siege conducted there, that it was not fitted with fortifications and it could not therefore fall into the category of an $\bar{a} t \bar{a} m$, the fortified tower-houses found in the city at the time (see above, n. 59; cf. al-'Alī 1961). Moreover, we are indirectly informed by some details in the account that the building should have had a courtyard and a wooden saqîfa (Ṭabarī VI [1898], 3013, 3018), both constituting elements of the $d \bar{a} r$ architectural type (above, note 3).

71 Tabarī VI [1898], 3005, 3009.

72 This particular device features the presence of the palace leaning against the qibli wall.

73 Cf. n. 27.

74 As noted by Bisheh, the existence of a private entrance owned by Abū Bakr cited in some sources may be a later invention, for the news refers to the time of the death of the Prophet, i.e. when Abū Bakr still lived in alSuhn, as pointed out above. 
for it became known as $b \bar{a} b$ 'Uthmān. ${ }^{75}$ It is interesting to note that the very first private door we have information about was a khawkha ${ }^{76}$ in the qibli wall opened as a sort of compensation after the demolition of Hafșa's hujra. ${ }^{77}$ Although this seems to represent a plausible prototype of the mosque-dār al-imāra combination - in the form of a residence ${ }^{78}$ situated on the qibla side of the mosque and somehow directly connected with the sanctuary - we should remember that this particular complex, besides having been built without true programmatic intent, was never devoted to caliphal use since 'Umar was already dead by the time the door was opened and the link created. ${ }^{79}$

Conversely, it is remarkable to observe how this programmatic will began to emerge with the advent of Umayyad authority and reached its peak with the rebuilding of the mosque by al-Walīd I (707-10). Marwān b. al-Hakim, Mu'āwiya's governor of Madīna (661-668 and 674-677), ${ }^{80}$ was the very first representative of caliphal authority to create a door in the sanctuary for his exclusive use, although not in the qibli wall. This door, originally known as $b \bar{a} b$ Marwān and later as $b \bar{a} b$ al-Salām, ${ }^{81}$ was located on the west side of the mosque ${ }^{82}$ and connected the prayer hall with a paved path ${ }^{83}$ leading to Marwān's residence ${ }^{84}$ which, according to the sources, stood south-west of the congregational building. ${ }^{85}$

\section{CONCLUSIONS}

In conclusion, although the emergence of a private connection serving the governor's visits to the great mosque can be dated to the Sufyanid period, we cannot yet talk about a proper mosque-dār al-imāra combination. Rather, we have to assume that Marwān's hișn stood separately from the congregational building, at a distance of ca. 20 cubits, as this was the amount by which it was enlarged westwards under al-Walīd I in 707-710 and which, based on the silence of the sources on the matter, presumably did not affect the structure of

Cf. above, 215, 217.

A window-like aperture opened onto the mosque (Bisheh 1979, 140; Lane 1968, II, 518).

Ibn Rusta, 71; Samhūdī I, 360-361, 375, 510.

The $d \bar{a} r$ of the descendants of 'Umar.

I.e. in 649, during 'Uthmān's caliphate.

30 Bosworth 1991, 621.

81 It is noteworthy that the $b \bar{a} b$ al-Salām was still part of the mosque rebuilt by al-Walīd, who enlarged the building westwards reconstructing the west side ex-novo. As suggested by Sauvaget, we have reason to believe that this door, much like other historical architectural elements in the mosque, «répond à une entrée ancienne, refaite sur un nouvel emplacement voisin de sa position originelle, et ayant retenu le nom sous lequel elle était connue antérieurement aux travaux d'al-Walīd» (Sauvaget 1947, 77; cf. Bisheh 1979, 158).

82 Sauvaget 1947, 77; Bishesh 1979, 158, 323, n. 152.

83 Bisheh 1979, 94.

84 It is worth noting that Marwān's residence became known as al-hișn al- 'atīq, namely "the ancient fortress" (Whitcomb 2008, 20). We therefore have reason to believe that it was a fortified place, although it is not clear from the sources whether it was already equipped with fortifications during Marwān's wilāya or whether it acquired the appearance of a hiṣn at a later stage. For a thorough analysis of the hiṣn architectural type, see Terrasse (1986).

85 Significantly, what happened in Madīna during Marwān's wilāya reflects the phenomenon attested in both Kūfa and Bașra in the same period (i.e. during Mu'āwiya's caliphate), when Ziyād b. Abīhi realised a connection between the congregational mosque and his residence. 
Marwān's $d \bar{a} r .{ }^{86}$ We could speculate, conversely, that one of the aims of this enlargement was to create the structural connection between the mosque and the palace which, over the years, had become the official seat of the city government and, most remarkably, the place where the caliph himself resided during his visits to Madīna. ${ }^{87}$ It is not coincidental that the first $b \bar{a} b$ al-Imām ${ }^{88}$ was created in the building at the same time, which, together with the $m i h r a \bar{b} b$ and the axial transept, seems to act as part of a royal device with a specific ritual purpose. Reading between the lines of Tabarī's account of al-Walīd I' first inaugural visit to the congregational building ${ }^{89}$ may in fact seem to suggest elements of a well-defined ceremonial fitting the architectural frame of the Marwānid mosque and involving a connection with the palace. An etiquette which - to some extent following that of the caliphal audiences - was conceivably linked to the bay'a (pledge of allegiance) and precisely when it was pledged to designated successor of the caliph probably in the congregational mosque. ${ }^{90}$

The concept of the ritualized paying of allegiance to the wali al- 'ahd ${ }^{91}$ acquired substance in the context of the bloody fratricide wars over succession that characterized the Umayyad era, and that probably to a large extent influenced the architecture of the mosque and the dār al-imāra.

\section{REFERENCES}

ABDELRAHMAN, E.

2010 The Influence of Hadith on the Architecture of Early Congregational Mosques, PhD Diss., ABŪ DĀ' ŪD University of Leeds 2010 (unpublished).

2008 Sunān, tr. Y. Qadhi, Sunan Abu Dawud, Riyadh 2008.

AкKоUсH, M.

1940 Contribution à une étude des origines de l'architecture musulmane, La Grande Mosquée de Médine (al-Haram al-Madanī): Mélanges Maspero III. Orient islamique, Le Caire 1940, pp. 377-410.

AL-'Alī, S.AH.

1961 Studies in the Topography of Medina (during the $1^{\text {st }}$ century AH): Islamic Culture 35.2 (1961), pp. 65-92.

86 al-Walīd enlarged the mosque by 44.5 cubits from east to west (Bisheh 1979, 211); since we know that he added five columns in the sanctuary to the right of the mihrāb (Bisheh 1979, 214; cf. Sauvaget 1947, 71-73), we can calculate that the western side was shifted westwards by ca. 25 cubits (calculating an approximate value of 5 cubits for each intercolumniation).

87 Indirect information on this comes from an episode related by Ibn al-Najjār according to which the caliph Sulaymān b. 'Abd al-Malik ordered the demolition of the south-western minaret because it overlooked the house of Marwān, where the caliph resided during a visit to Madīna in 97 A.H. (Bisheh 1979, 211-212, 331, n. 188).

88 I.e. a door flanking the mihrāab and giving access to the maqșüra reserved for the exclusive use of the caliph or the governor during the Friday prayer (Sauvaget 1947, 85).

89 Ṭabarī II [1881-82], 1233-1234.

90 For an in-depth discussion of the ritual of the bay ' $a$ and its development throughout the Umayyad era, see Marsham 2009.

91 Designated heir to the throne (Marsham 2009, 113-122). 
AYYAD, E.S.

2013 The 'House of the Prophet' or 'the Mosque of the Prophet'?: Journal of Islamic Studies 24.3 (2013), pp. 274-334.

2015 'I Have not Been Commanded to Apply Tashyīd to Mosques': A Prophetic Perspective of Mosque Architecture: The Islamic Quarterly 59 (2015), pp. 1-34.

AL-BAGHAWI

1971 Sharh al-sunna, Beirut 1971.

BALĀDHURİ

1916 Kitāb Futūh al-Buldān, tr. P.K. Hitti, The Origins of the Islamic State, being a translation from the Arabic accompanied with annotations geographic and historic notes of the Kitâb BISHEH, GH.I. futûh al-buldân of al-Imâm abu-l 'Abbâs Ahmad ibn Jâbir al-Balâdhuri, New York 1916.

1979 The Mosque of the Prophet at Madinah throughout the First Century A.H. with Special Emphasis on the Umayyad Mosque, PhD Diss., University of Michigan 1979 (unpublished).

BOSWORTH, C.E.

1991 Marwān b. al-Hakim: The Encyclopaedia of Islam² VI, Leiden 1991, pp. 621-623.

BUKHĀRĪ

1997 Sahịhh, tr. M. M. Khan, Sahîh al-Bukhâri, Arabic-English, Riyad 1997.

CAETANI, L.

1905 Annali dell'Islām, I, Milano 1905.

CRESWELL, K.A.C.

1979 Early Muslim Architecture, I/1. Umayyads A.D. 622-750, New York $1979^{2}$ [Revisited DIYĀRBAKRİ

1884 Tà'rīkh al-Khamīs fì ahwāl anfas nafìs, al-Miṣr 1884.

AL-HARBĪ

1969 Kitāb al-manāsik wa-amākin țuruq al-hajj wa-ma 'ālim al-Jazīrah, al-Riyāọ 1969.

IBN AL-FAQі̄H

1973 Mukhtașar Kitāb al-buldān, tr. H. Massé, Ibn al-Faq̄ih al-Hamaḍ̄n̄ī, Abrégé du Livre des IBN KATHĪR Pays Traduit de l'arabe par Henri Massé, Damas 1973.

1997 al-Bidāya wa al-Nihāya, Beirut 1997.

IBN AL-NAJJĀR

1956 al-durra al-thamīna fì akhbār al-Madīna, Makkah 1956.

IBN RUSTA

1955 Kitāb al-a lāq al-nafisa, tr. G. De Wiet, Ibn Rusteh, Les atours précieux, Le Caire 1955.

IBN SA D

n.d. Kitāb al-tabaqāt al-kabīr, tr. S. Moinul Haq, Ibn Sa'd’s Kitab al-tabaqat al-kabir, New

JOHNS, J.

1999 The 'House of the Prophet' and the Concept of the Mosque: J. RABY - J. Johns (eds.), Bayt al-Maqdis: Jerusalem and Early Islam (Oxford Studies in Islamic Art IX), Oxford LANE, E.W. 1999, pp. 59-112.

1968 An Arabic-English Lexicon: in eight parts, Beirut 1968.

LECKER, M.

1995 Muslims, Jews and Pagans, Studies on Early Islamic Medina, Leiden - New York - Köln 1995. 
XXI (2017) The role of Madīna in the emergence of the Mosque-Dār al-Imāra combination

AL-MARĀGHĪ

1955 Taḥqīq al-nușrah bi-talkhīṣ ma à̃lim dār al-hijra, al-Madīna 1955.

MARSHAM, A.

2009 Rituals of Islamic Monarchy: Accession and Succession in the First Muslim Empire, Edinburgh 2009.

PEDERSEN, J.

1991 Masdjid: The Encyclopaedia of Islam² VI, Leiden 1991, pp. 645-646.

RODED, R.

$2000 \quad$ Umm Salama Hind: The Encyclopaedia of Islam² X, Leiden 2000, p. 856.

SAMHŪDĪ

1908 Wafă' al-wafä' bi-akhbār dār al-muștafā, al-Mișr 1908.

SAUVAGET, J.

1947 La mosquée omeyyade de Médina, Paris 1947.

ȚABARĪ

1879-1901 Ta'rīkh al-rusul wa al-mulūk: M.J. DE GoeJE (ed.), Annales quos scripsit Abu Djafar Mohammed Ibn Djarir At-Tabari, Lugduni Batavorum 1879-1901.

TERRASSE, $\mathrm{H}$.

1986 Hisn: The Encyclopaedia of Islam² III, Leiden 1986, pp. 498-501.

AL-TIRMIDHī

1986 Sunān al-Tirmidhī, Beirut 1986.

WATT, M.

1960 al- 'Abbās b. 'Abd al-Muțalib: The Encyclopaedia of Islam² I, Leiden 1960, p. 9.

WELLHAUSEN, J.

1902 Das arabische Reich und sein Sturz, Berlin 1902.

WHITCOMB, D.

2008 An Urban Structure for the Early Islamic City: A.K. BenNinson - A.L. GAsCoIGne (eds.), Cities in the Pre-Modern Islamic World, London - New York 2008, pp. 15-26.

AL-YA'QūBĪ

1937 Kitāb al-buldān, tr. G. Wiet, Ya kāūbī, Les Pays, Le Caire 1937. 

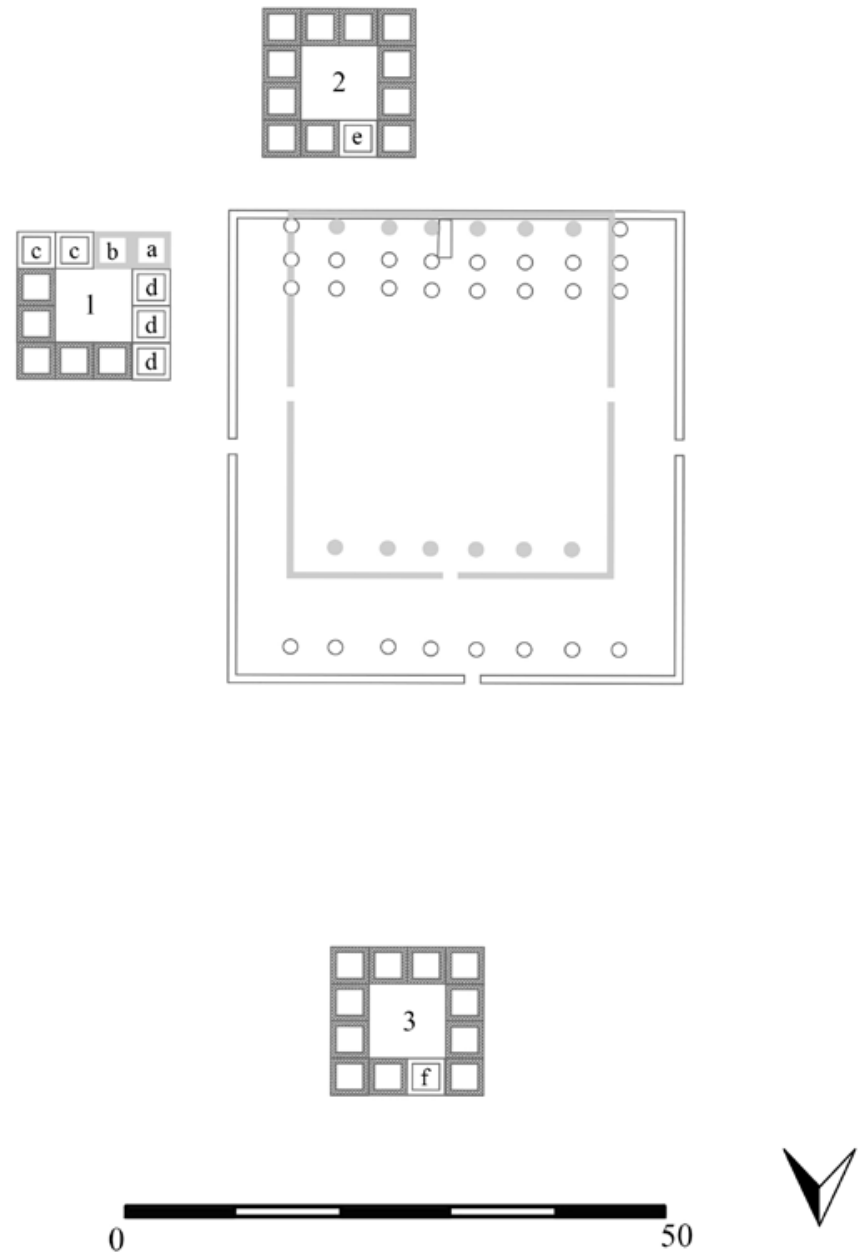

$\begin{array}{llll} & \text { a. 'Ā'isha's hujra } & \\ \text { Phase 1 (622-628) } & \text { b. Sawda's hujra } & \text { 1. Prophet's dār } \\ \text { Phase 2 (628-638) } & \text { c. Umm Salama's hujira (?) } & \text { 2. Umar b. al-Khațāā's dār } \\ \text { Conjectural } & \text { d. 'Alī and Fāțima's hujrāt } & \text { 3. Wives' northern dār } \\ & \text { e. Hafșa's hujra } & \\ & \text { f. Safiya's hujra }\end{array}$

Fig. 1 - Madina: Mosque of the Prophet and adjoining dwelling quarters during Muhammad's lifetime (622-638 AD; drawing by the author). 


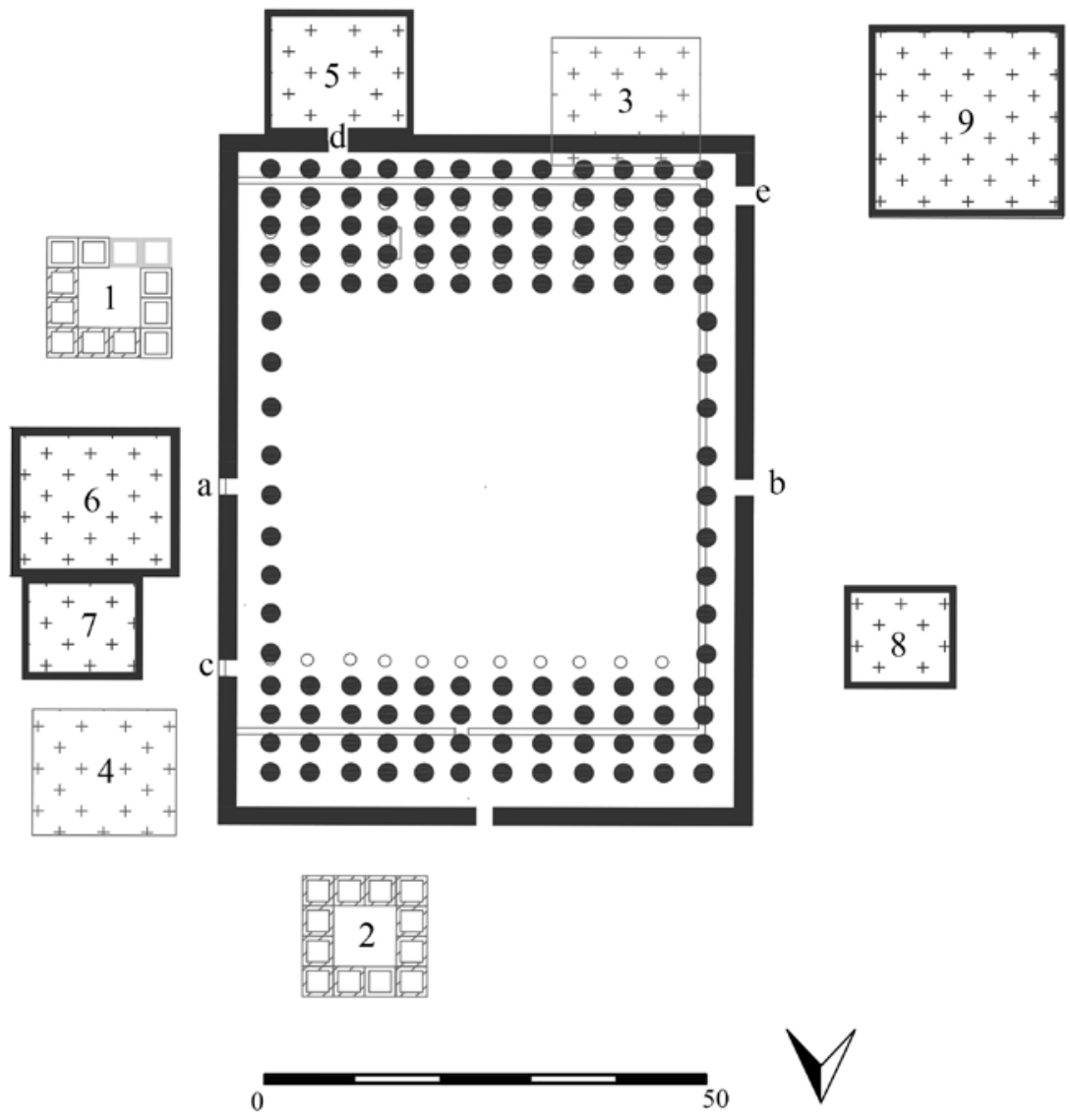

$\square$ Phase 3 (638-649)
$\square$ Phase 4 (649-707 ca.)
$\square 7$ Conjectural rooms
$+\quad+$ Unknown plan
a. bāb Jibrīl
b. bāb al-Raḥmān
c. bāb al-Nisā'
d. khawkha of the heirs of 'Umar
e. bāb Marwān

\author{
1. Prophet's $d \bar{a} r$ \\ 2. Wives' northern $d \bar{a} r$ \\ 3. al- 'Abbās b. 'Abd al-Muțtalib's dār \\ 4. Abū Bakr's dār \\ 5. dār of the heirs of 'Umar \\ 6. 'Uthmān's dār \\ 7. 'Amr b. Ḥazan al-Anșārī's dār \\ 8. Ḥassān b. Thābit's utum \\ 9. Marwān b. al-Hakim's dār
}

Fig. 2 - Madina: Mosque of the Prophet and adjoining dwelling quarters after the rebuilding by the caliphs 'Umar and 'Uthmān (ca. 638-707 AD; drawing by the author). 